\title{
A WIDE SPECTRUM OF ANTIBACTERIAL ACTIVITY OF SECONDARY METABOLITES FROM Bacillus amyloliquefaciens ELI149
}

\section{UM AMPLO ESPECTRO DE ATIVIDADE ANTIBACTERIANA DOS METABÓLITOS SECUNDÁRIOS DE Bacillus amyloliquefaciens ELI149}

\author{
Estibaliz SANSINENEA ${ }^{1 *}$; Jessica VACA ${ }^{1}$; Norma Elena ROJAS ${ }^{2}$; Candelario VÁZQUEZ ${ }^{2}$ \\ 1. Facultad de Ciencias Químicas, Benemérita Universidad Autónoma de Puebla, Puebla, México. 2. Centro de Investigaciones en \\ Ciencias Microbiológicas, ICUAP, Benemérita Universidad Autónoma de Puebla, Puebla, México. estisansi@yahoo.com.mx
}

\begin{abstract}
A highly potent secondary metabolites-producing Bacillus strain was isolated from Mexican soil (Puebla State), together with other fifty strains. The fifty-one strains were subjected for metabolites extraction and evaluated as antibacterial against several bacteria. The active metabolites of these strains were extracted using amberlite XAD16 absorbent resin. The antibacterial activity of crude extracts of all strains was performed by disk diffusion method against some pathogenic gram positive and gram-negative bacteria. Among all Bacillus strains tested, the most potent strain ELI149 (NRB) was selected for molecular characterization. The nucleotide sequence of the 16S rRNA gene (1.5 $\mathrm{Kb}$ ) of this strain evidenced a 94\% similarity with Bacillus amyloliquefaciens strain IIHR-Ba-2, which showed the highest inhibition against the most bacteria probed even greater inhibition than the standard antibiotic. In conclusion, secondary metabolites extracted from Bacillus amyloliquefaciens strain are highly potent as antibiotic against the most bacteria probed. Identification of which metabolites extracted from amberlite are the responsible of the bacteria growth inhibition will be a challenge.
\end{abstract}

KEYWORDS: Antibacterial. Amberlite. Bacillus amyloliquefaciens. Secondary metabolites.

\section{INTRODUCTION}

A few decades after the introduction of antibiotics into clinical practice, resistance by pathogenic bacteria has become a major health concern. Actually, many gram-positive bacteria and gram-negative opportunistic pathogens are becoming resistant to virtually every clinically available drug, diminishing therapy options for multiresistant bacterial pathogens (BRUNEL; GUERY, 2017). Therefore, new antibiotics are urgently needed to improve the management of bacterial infections. Parallel to the screening for new antibiotics, efforts have been focused in finding low molecular weight secondary metabolites with other biological activities (NUTI et al., 2017). Secondary metabolites with antimicrobial properties have been used for many years. Secondary metabolites play a significant role in clinical practice due to their activity as antimicrobials used in the treatment of microbial induced infections. Furthermore, the wide diversity of secondary metabolites suggests a broad range of functions (VAISHNAV; DEMAIN, 2011; WRIGHT, 2014).

Bacillus species produce secondary metabolites that are the object of natural product chemistry studies. The wide structural variability of these compounds has attracted the curiosity of chemists and their biological activities have inspired the pharmaceutical industry to search for lead structures in microbial extracts. Screening of microbial extracts reveals the large structural diversity of natural compounds with broad biological activities, such as antimicrobial, antiviral, immunosuppressive, and antitumor activities, that enable the bacterium to survive in its natural environment. These findings widen the potential industrial importance of Bacillus spp (SANSINENEA, 2012; SANSINENEA; ORTIZ, 2011).

Among them, the plant root-colonizing Bacillus amyloliquefaciens is a naturally occurring isolate, distinguished from the model organism Bacillus subtilis by its abilities to stimulate plant growth and suppress plant pathogens. Therefore, $B$. amyloliquefaciens species were reported effective for the biocontrol of multiple plant diseases caused by soilborne (CHEN et al., 2009) or post-harvest pathogens (ARGUELLES-ARIAS et al., 2009).

The aim of this study was to evaluate the potential of different bacterial strains to produce biologically active substances with antibacterial activity.

\section{MATERIAL AND METHODS}

Microorganisms and growth conditions

Bacillus spp. fifty-one isolates were 
collected from soils of different States (Puebla, San Luis Potosi, Queretaro, Tabasco, Quintana Roo and Yucatan) from Mexico. The gram-negative bacteria used as target to probe the antibiotic activity of the Bacillus extracts were Klebsiella pneumoniae, Serratia marcescens, Escherichia coli, Shigella sp, Salmonella choleraesuis, Vibrio cholerae, Vibrio parahaemolyticus and Pseudomonas aeruginosa; the gram-positive bacteria used as target were Micrococcus luteus, Staphylococcus aureus, Staphylococcus saprophyticus, Streptococcus agalactiae, Listeria monocytogenes and Bacillus cereus.

For the growth of all bacteria they were cultured in conic tubes with $3 \mathrm{~mL}$ of LB (Luria Bertani) medium at $175 \mathrm{rpm} / \mathrm{min}$ at $29^{\circ} \mathrm{C}$ overnight. For the extraction of the secondary metabolites Bacillus spp. strains were cultured in $500 \mathrm{~mL}$ Erlenmeyer flasks containing $250 \mathrm{~mL}$ of (tripticasein soy broth) TSB medium and amberlite XAD-16 adsorbent resin in a rotary shaker at 175 $\mathrm{rpm} / \mathrm{min}$ at $29{ }^{\circ} \mathrm{C}$ for $7 \mathrm{~d}$. On completion of the culture, the bacteria were removed by centrifugation at $6000 \mathrm{rpm} / \mathrm{min}$ for $10 \mathrm{~min}$, and the supernatant was used for the extraction of the metabolites.

\section{Extraction of antibiotic crude substances with amberlite XAD-16 adsorbent resin and with ethyl acetate solvent}

The crude antibiotic substances were recovered from the culture filtrate of different isolates with the XAD-16 adsorbent resin. Briefly, The Bacillus spp. strains were inoculated into 500 $\mathrm{mL}$ Erlenmeyer flasks, containing $250 \mathrm{~mL}$ of TSB (tripticasein soy broth) medium. XAD-16 adsorbent resin (1.25 grams) was added and the culture was incubated with shaking at $29{ }^{\circ} \mathrm{C}$ for 7 days. The adsorbent resin was recovered from the culture broths by decantation, and the resin was washed with $60 \mathrm{~mL}$ of methanol until the amberlite returned to its white color. The methanol was filtered through $0.45 \mu \mathrm{m}$ membranes to eliminate any spores and evaporation of the methanol yielded a crude extract which was retained for further studies.

The crude antibiotic substances of the strain ELI149 (NRB) were also recovered from the culture filtrate by solvent extraction with ethyl acetate. Ethyl acetate was added to the filtrate at a ratio of $3: 1(\mathrm{v} / \mathrm{v})$ and shaken vigorously. The organic layer was collected and evaporated to dryness to yield a crude extract.

Ethyl acetate solvent was also used to extract compounds from amberlite. For this the adsorbent resin was recovered from the culture broth by decantation and washed with aqueous methanol. After evaporation, the remaining aqueous mixture was extracted four times with ethyl acetate.

\section{Determination of antibacterial activity of antibiotic crude substances against several bacteria}

$15 \mathrm{mg}$ of the crude extract were dissolved in $100 \mathrm{ml}$ of distilled sterile water. Sterile filter paper disks containing $10 \square \mathrm{L}$ of crude extract (150 $\mathrm{mg} / \mathrm{mL}$ ) were placed on plates of LB and MullerHinton agar seeded with $100 \square \mathrm{L}$ of suspensions of one day old cultures of bacteria tested. The suspensions were adjusted to give a concentration of approximately $10^{5} \mathrm{CFU}$ per $\mathrm{mL}$. The negative control was a sterile disk impregnated with distilled water and control positive was the antibiotic ampicillin $(150 \mathrm{mg} / \mathrm{mL})$ for gram negative bacteria and vancomycin $(50 \mathrm{mg} / \mathrm{mL})$ for gram positive bacteria. The diameters of the zones of inhibition of growth around the disks were measured after incubation periods of one day at $29{ }^{\circ} \mathrm{C}$. The experiments were performed as three independent replicates.

\section{Molecular characterization}

Genomic DNA was extracted according to Sambrook et al. (1989) and was treated with $5 \mu \mathrm{L}$ of $\mathrm{RNase}$. The bacterial isolates were characterized by employing 16S rRNA gene specific primers TBAX101 (5'AGGAGGTGATCCAACCGCA3') and TBAX1 (5'AGAGTTTGATCATGGCTCA3') which were designed in our laboratory based on genomic sequences of $B$. thuringiensis resulting in an amplicon size of $1.5 \mathrm{~Kb}$. Polymerase Chain Reaction (PCR) was carried out in $25 \mu \mathrm{L}$ total reaction volume, that contained the following components: template $(50 \mathrm{ng} / \mu \mathrm{l}), 20 \mathrm{pmol}$ of each primer, $10 \mathrm{mM}$ Tris- $\mathrm{HCl}$ (pH-8.3), $50 \mathrm{mM} \mathrm{KCl}, 2.5$ $\mathrm{mM} \mathrm{MgCl} 2,0.25 \mathrm{mM}$ of each dNTP and $0.5 \mathrm{U}$ of Taq DNA polymerase and the rest was made up with water. PCR was carried out in a thermal cycler Eppendorf with the following cycling parameters; $94{ }^{\circ} \mathrm{C}$ for $4 \mathrm{~min}$ as initial denaturation followed by 25 cycles of $94{ }^{\circ} \mathrm{C}$ for $30 \mathrm{~s}, 54{ }^{\circ} \mathrm{C}$ for $30 \mathrm{~s}, 72{ }^{\circ} \mathrm{C}$ for $45 \mathrm{~s}$ and $72{ }^{\circ} \mathrm{C}$ for $8 \mathrm{~min}$ as final extension. The amplified products were resolved in $0.8 \%$ agarose gel, stained with ethidium bromide $(10 \mu \mathrm{g} / \mathrm{mL})$ and visualized in a gel documentation system.

\section{Sequencing and analysis of $16 \mathrm{~S}$ rRNA gene}

The $1.5 \mathrm{~Kb}$ fragments obtained by PCR for detect 16S rRNA gene were purified following the protocol of cleaning PCR products specified by QIAGEN QIAquick kit. A sample, of $60 \mathrm{ng} / \mu \mathrm{L}$ of PCR product (purified and without cloning), was 
used for it sequencing which was carried out in Genomic Services LANGEBIO CINVESTAV, Guanajuato. Homology search was carried out using BLAST (http://www.ncbi.nlm.nih.gov) and sequences of various bacteria were further analyzed employing MEGA 5.0 (TAMURA et al., 2011). Sequence data from the most active isolate was used to construct a phylogenetic tree using the maximum likelihood method (FELSENSTEIN, 1981). The other GenBank accession numbers used to construct the tree are KT906687.1, KP997272.1, KT021505.1, KT375322.1, KT151933.1, JF513129.1， KJ545589.1， GU085100.1, JF901341.1, JQ410791.1.

\section{RESULTS AND DISCUSSION}

\section{Extraction of antibiotic crude substances}

With the intention to evaluate the antibiotic activity of the crude substances produced by
Bacillus strains, these were successfully extracted from all tested strains of Bacillus spp. using XAD16 adsorbent resin. Dried extracts were brown in color and their weights obtained were between 1 and $2 \mathrm{~g} / \mathrm{L}$ of the extract for all strains. For ELI149 (NRB) strain secondary metabolites were also extracted using ethyl acetate as a solvent giving an oily yellow extract.

\section{Determination of antibacterial activity of crude substances from Bacillus spp}

The results showed that ELI149 (NRB) strain, which results are marked in blue in Table 1, was the most effective against almost all bacteria probed, indicating that the secondary metabolites secreted by this strain have a wide spectrum of activity, as it can be seen in Table 1.

Table 1. Diameters ( $\mathrm{mm}$ ) of the zones of inhibition of growth of gram-positive and gram-negative bacteria of the extracts of fifty-one strains probed.

\begin{tabular}{|c|c|c|c|c|c|c|c|c|c|c|c|c|c|c|}
\hline $\begin{array}{c}\text { Stra } \\
\text { in }\end{array}$ & \begin{tabular}{l}
\multicolumn{1}{c}{$S}$. \\
saprop \\
hyticu \\
S
\end{tabular} & $\begin{array}{c}\text { L. } \\
\text { monoc } \\
\text { ytogen } \\
\text { es }\end{array}$ & $\begin{array}{c}S . \\
\text { agal } \\
\text { actia } \\
e\end{array}$ & $\begin{array}{l}S \\
\text { au } \\
\text { reu } \\
\text { s }\end{array}$ & $\begin{array}{c}B . \\
c e r \\
e u \\
s\end{array}$ & $\begin{array}{l}\text { M. } \\
\text { lut } \\
\text { eu } \\
\text { s }\end{array}$ & $\begin{array}{c}S . \\
\text { chole } \\
\text { raesui } \\
\text { S }\end{array}$ & $\begin{array}{l}E \\
\text { E } \\
c \\
o \\
l i\end{array}$ & $\begin{array}{l}K . \\
\text { pneu } \\
\text { moni } \\
\text { ae }\end{array}$ & $\begin{array}{l}\text { Shi } \\
\text { gell } \\
a \\
s p\end{array}$ & $\begin{array}{c}P . \\
\text { aeru } \\
\text { ginos } \\
a\end{array}$ & $\begin{array}{c}V . \\
\text { parahae } \\
\text { molyticu } \\
\text { S }\end{array}$ & $\begin{array}{c}\text { V. } \\
\text { chol } \\
\text { era } \\
e\end{array}$ & $\begin{array}{c}S . \\
\text { marc } \\
\text { escen } \\
S\end{array}$ \\
\hline $\begin{array}{c}\text { ELI } \\
1\end{array}$ & 0 & 0 & 0 & 0 & 10 & 0 & 0 & 0 & 0 & 0 & 0 & 0 & 0 & 0 \\
\hline $\begin{array}{c}\text { ELI } \\
2\end{array}$ & 8 & 0 & 0 & 0 & 12 & 10 & 0 & 0 & 0 & 0 & 0 & 0 & 0 & 15 \\
\hline $\begin{array}{c}\text { ELI } \\
\mathbf{3}\end{array}$ & 0 & 0 & 18 & 30 & 11 & 23 & 6 & 7 & 6 & 0 & 0 & 0 & 0 & 10 \\
\hline $\begin{array}{c}\text { ELI } \\
4\end{array}$ & 0 & 0 & 0 & 23 & 10 & 10 & 0 & 0 & 0 & 0 & 0 & 0 & 0 & 20 \\
\hline $\begin{array}{c}\text { ELI } \\
5\end{array}$ & 12 & 10 & 0 & 26 & 12 & 15 & 0 & 0 & 0 & 0 & 0 & 0 & 0 & 20 \\
\hline $\begin{array}{c}\text { ELI } \\
6\end{array}$ & 0 & 0 & 10 & 15 & 0 & 10 & 0 & 0 & 0 & 0 & 0 & 0 & 0 & 8 \\
\hline $\begin{array}{c}\text { ELI } \\
7\end{array}$ & 0 & 0 & 8 & 20 & 12 & 14 & 0 & 0 & 0 & 8 & 0 & 0 & 0 & 13 \\
\hline $\begin{array}{c}\text { ELI } \\
8\end{array}$ & 0 & 0 & 0 & 20 & 0 & 7 & 0 & 0 & 0 & 0 & 0 & 0 & 0 & 15 \\
\hline $\begin{array}{c}\text { ELI } \\
9\end{array}$ & 7 & 10 & 11 & 14 & 12 & 16 & 0 & 0 & 0 & 0 & 0 & 0 & 0 & 23 \\
\hline $\begin{array}{c}\text { ELI } \\
10\end{array}$ & 0 & 0 & 13 & 14 & 0 & 10 & 0 & 0 & 0 & 0 & 0 & 0 & 0 & 11 \\
\hline $\begin{array}{c}\text { ELI } \\
11\end{array}$ & 0 & 0 & 0 & 13 & 0 & 0 & 0 & 0 & 0 & 0 & 0 & 0 & 0 & 10 \\
\hline $\begin{array}{c}\text { ELI } \\
12\end{array}$ & 0 & 0 & 0 & 12 & 0 & 10 & 0 & 0 & 0 & 0 & 0 & 0 & 0 & 12 \\
\hline $\begin{array}{c}\text { ELI } \\
13\end{array}$ & 11 & 10 & 0 & 30 & 11 & 17 & 0 & 0 & 0 & 0 & 0 & 0 & 0 & 13 \\
\hline
\end{tabular}


A wide spectrum...

$\begin{array}{lllllllllllllll}\text { ELI } & 0 & 0 & 0 & 15 & 12 & 0 & 0 & 0 & 0 & 0 & 0 & 0 & 0 & 10\end{array}$

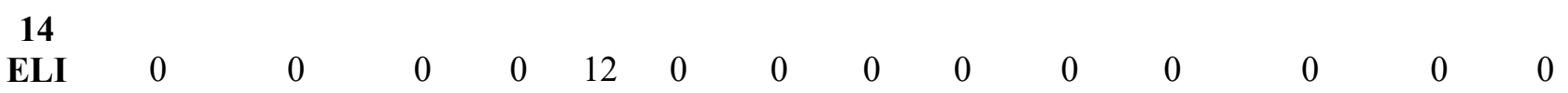
$\begin{array}{lllllllllllllll}15 & & & & & & & & & & & & \\ \text { ELI } & 0 & 0 & 0 & 0 & 0 & 0 & 0 & 0 & 0 & 0 & 0 & 0 & 0 & 7\end{array}$ 16 $\begin{array}{lllllllllllllll}\text { ELI } & 0 & 0 & 11 & 23 & 15 & 0 & 0 & 0 & 0 & 0 & 0 & 0 & 0 & 12\end{array}$ 17

$\begin{array}{lllllllllllllll}\text { ELI } & 0 & 0 & 12 & 17 & 13 & 12 & 0 & 0 & 0 & 0 & 10 & 0 & 0 & 13\end{array}$

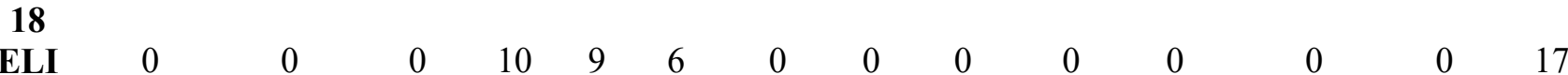
19

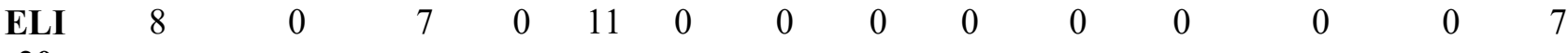
$\begin{array}{ccccccccccccccc}\mathbf{2 0} & & & & & & & & & & & \end{array}$ $\begin{array}{lllllllllllllll}\mathbf{2 1} & & & & & & & & & \end{array}$

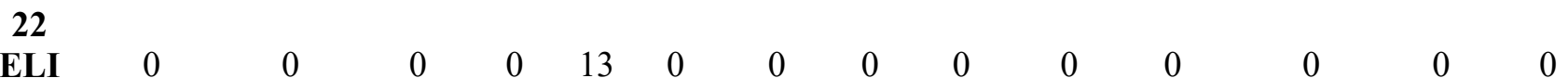
23

$\begin{array}{lllllllllllllll}\text { ELI } & 0 & 0 & 0 & 17 & 11 & 11 & 0 & 0 & 0 & 0 & 0 & 0 & 0 & 13\end{array}$ $\begin{array}{cllllllllllllll}\mathbf{2 4} & & & & & & & & & & & & & \end{array}$

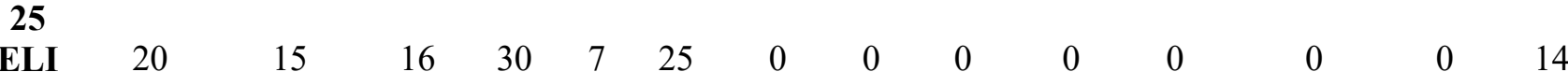
$\begin{array}{llllll}7 & 0 & 0 & 0 & 0 & 0\end{array}$ $\begin{array}{lllllllllllllll}\text { ELI } & 0 & 0 & 8 & 12 & 0 & 0 & 0 & 0 & 0 & 0 & 0 & 0 & 0 & 11\end{array}$ $\begin{array}{ccccccccccccccc}\mathbf{2 7} & & & & & & & & \end{array}$ $\begin{array}{lllllllllllllll}\mathbf{2 8} & & & & & & & & & & \end{array}$ 292015

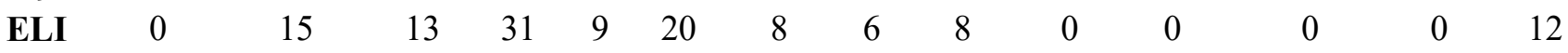
$\begin{array}{lllllllllllllll}\mathbf{3 0} & & & & & & & & & & & & \\ \text { ELI } & 0 & 15 & 15 & 24 & 0 & 15 & 0 & 0 & 0 & 0 & 0 & 0 & 0 & 9\end{array}$

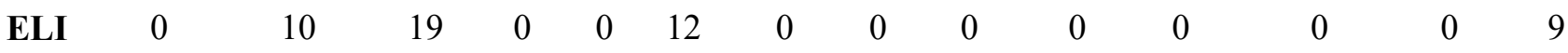

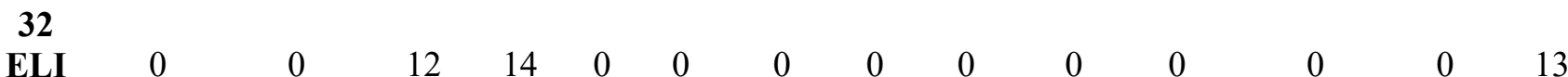
$\begin{array}{ccccccccccccccc}33 & & & & & & & & & & & & & & \\ \text { ELI } & 0 & 0 & 0 & 13 & 8 & 10 & 0 & 0 & 0 & 0 & 0 & 0 & 0 & 14\end{array}$ $\begin{array}{ccccccccccccccc}\text { ELI } & 0 & 0 & 0 & 13 & 8 & 10 & 0 & 0 & 0 & 0 & 0 & 0 & 0 & 14\end{array}$

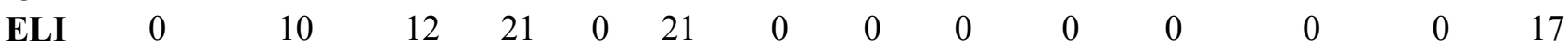
$\begin{array}{cllllllllllllll}\mathbf{3 5} & & & & & & & & & & & \\ \text { ELI } & 0 & 10 & 9 & 14 & 0 & 7 & 0 & 0 & 0 & 0 & 0 & 0 & 0 & 16\end{array}$ 36 $\begin{array}{lllllllllllllll}\text { ELI } & 0 & 10 & 12 & 24 & 0 & 22 & 0 & 0 & 0 & 0 & 0 & 0 & 0 & 25\end{array}$ 37 $\begin{array}{lllllllllllllll}\text { ELI } & 17 & 20 & 0 & 10 & 13 & 13 & 0 & 0 & 0 & 0 & 0 & 0 & 0 & 25\end{array}$ $\begin{array}{cccccccccccccccc}\mathbf{3 8} & & & & & & & & & & & & \end{array}$ $\begin{array}{cllllllllllllll}39 & & & & & & & & & \end{array}$

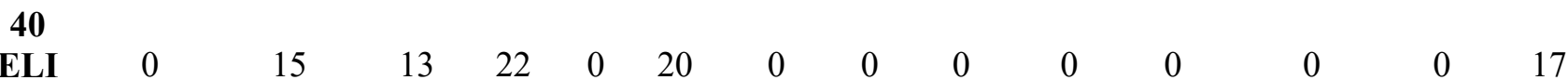




\begin{tabular}{|c|c|c|c|c|c|c|c|c|c|c|c|c|c|c|}
\hline $\begin{array}{c}41 \\
\text { ELI } \\
42\end{array}$ & 0 & 10 & 11 & 18 & 0 & 0 & 0 & 0 & 0 & 0 & 0 & 0 & 0 & 13 \\
\hline $\begin{array}{c}\text { ELI } \\
43\end{array}$ & 11 & 15 & 14 & 30 & 8 & 16 & 0 & 0 & 0 & 0 & 0 & 0 & 0 & 21 \\
\hline $\begin{array}{c}\text { ELI } \\
44\end{array}$ & 0 & 20 & 8 & 12 & 7 & 12 & 16 & 0 & 0 & 0 & 0 & 0 & 0 & 0 \\
\hline $\begin{array}{c}\text { ELI } \\
45\end{array}$ & 7 & 10 & 0 & 26 & 11 & 0 & 0 & 0 & 0 & 0 & 0 & 0 & 0 & 11 \\
\hline $\begin{array}{c}\text { ELI } \\
46\end{array}$ & 0 & 0 & 0 & 0 & 0 & 0 & 0 & 0 & 0 & 0 & 0 & 0 & 0 & 13 \\
\hline $\begin{array}{c}\text { ELI } \\
47\end{array}$ & 13 & 9 & 0 & 27 & 7 & 16 & 0 & 0 & 0 & 0 & 0 & 0 & 0 & 0 \\
\hline $\begin{array}{c}\text { ELI } \\
48\end{array}$ & 0 & 7 & 20 & 0 & 10 & 18 & 0 & 0 & 0 & 0 & 0 & 0 & 0 & 20 \\
\hline $\begin{array}{c}\text { ELI } \\
49\end{array}$ & 0 & 0 & 12 & 0 & 8 & 20 & 0 & 0 & 0 & 10 & 0 & 0 & 0 & 0 \\
\hline $\begin{array}{c}\text { ELI } \\
\mathbf{5 0}\end{array}$ & 0 & 0 & 10 & 0 & 8 & 21 & 0 & 0 & 0 & 10 & 0 & 0 & 0 & 0 \\
\hline $\begin{array}{c}\text { ELI } \\
149\end{array}$ & 17 & 20 & 12 & 25 & 10 & 36 & 7 & 7 & $\mathbf{0}$ & 12 & 7 & 10 & 14 & 45 \\
\hline $\begin{array}{c}\mathbf{A m} \\
\mathbf{p} / \mathbf{V a} \\
\mathbf{n}\end{array}$ & 30 & 28 & 21 & 45 & 19 & 40 & 22 & $\begin{array}{l}1 \\
8\end{array}$ & 8 & 24 & 7 & 10 & 10 & 36 \\
\hline
\end{tabular}

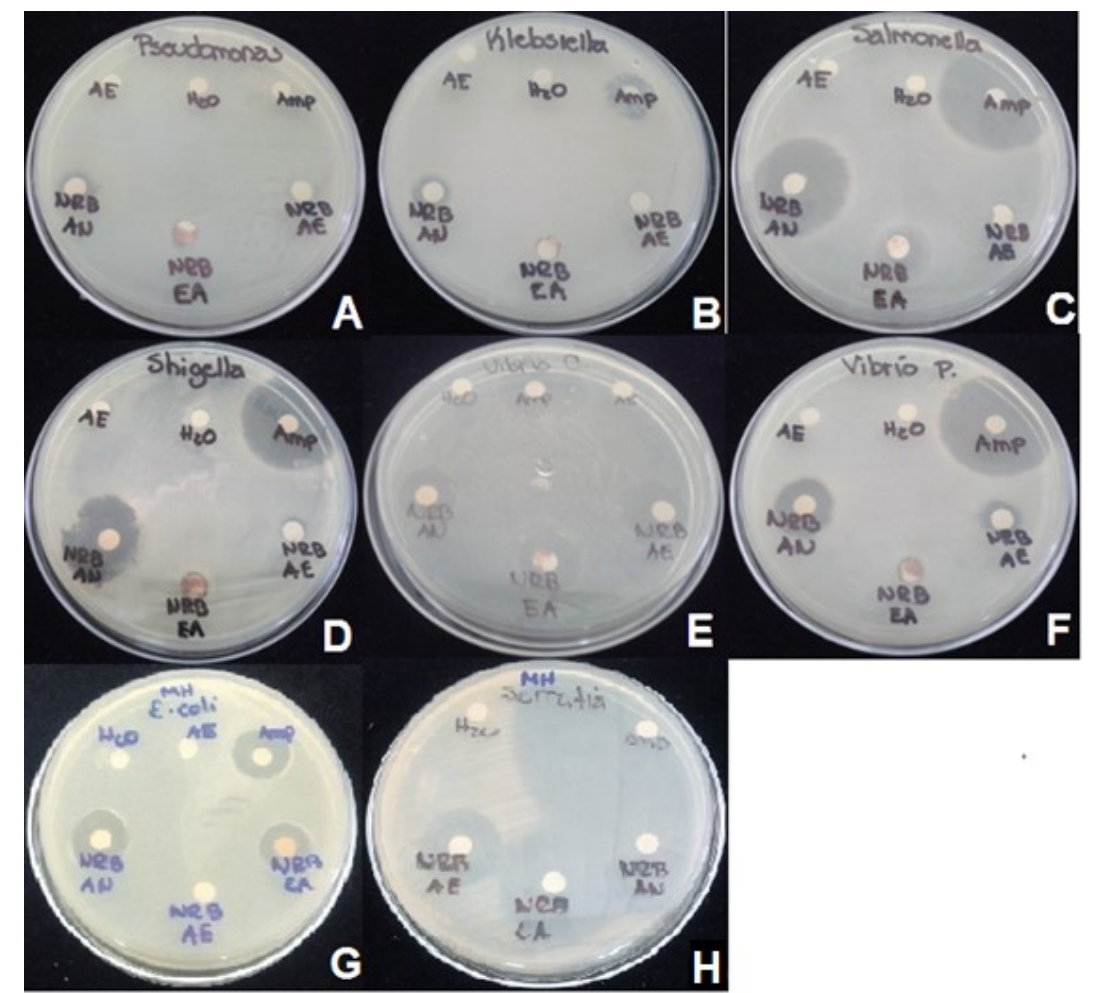

Figure 1. Determination of antibacterial activity of secondary metabolites of the crude extract of ELI149 (NRB) Bacillus sp. strain by agar-diffusion method in Muller-Hinton plates to the following gramnegative bacteria; A) P. aeruginosa, B) K. pneumonia, C) $S$. choleraesuis, D) Shigella sp., E) $V$. Cholerae, F) V. parahaemolyticus, G) E. coli, H) S. Marcescens

The assay was also done with the extracts of ethyl acetate solvent. The amberlite extracts (AN) are more effective against all bacteria than the extracts by ethyl acetate method (AE) and more 
effective than ethyl acetate solvent as extractor of the compounds from amberlite (EA) showing a major inhibition zone around the disks in the first case (AN). The results indicated that amberlite XAD-16 was better than solvent extraction to retain compounds with antibiotic activity. In some cases even the metabolites adsorbed by amberlite were as effective as standard antibiotic such as in E.coli case or even more such as P.aeruginosa and V.cholerae cases. Figure 2 shows the effect of the same extracts against grampositive bacteria.

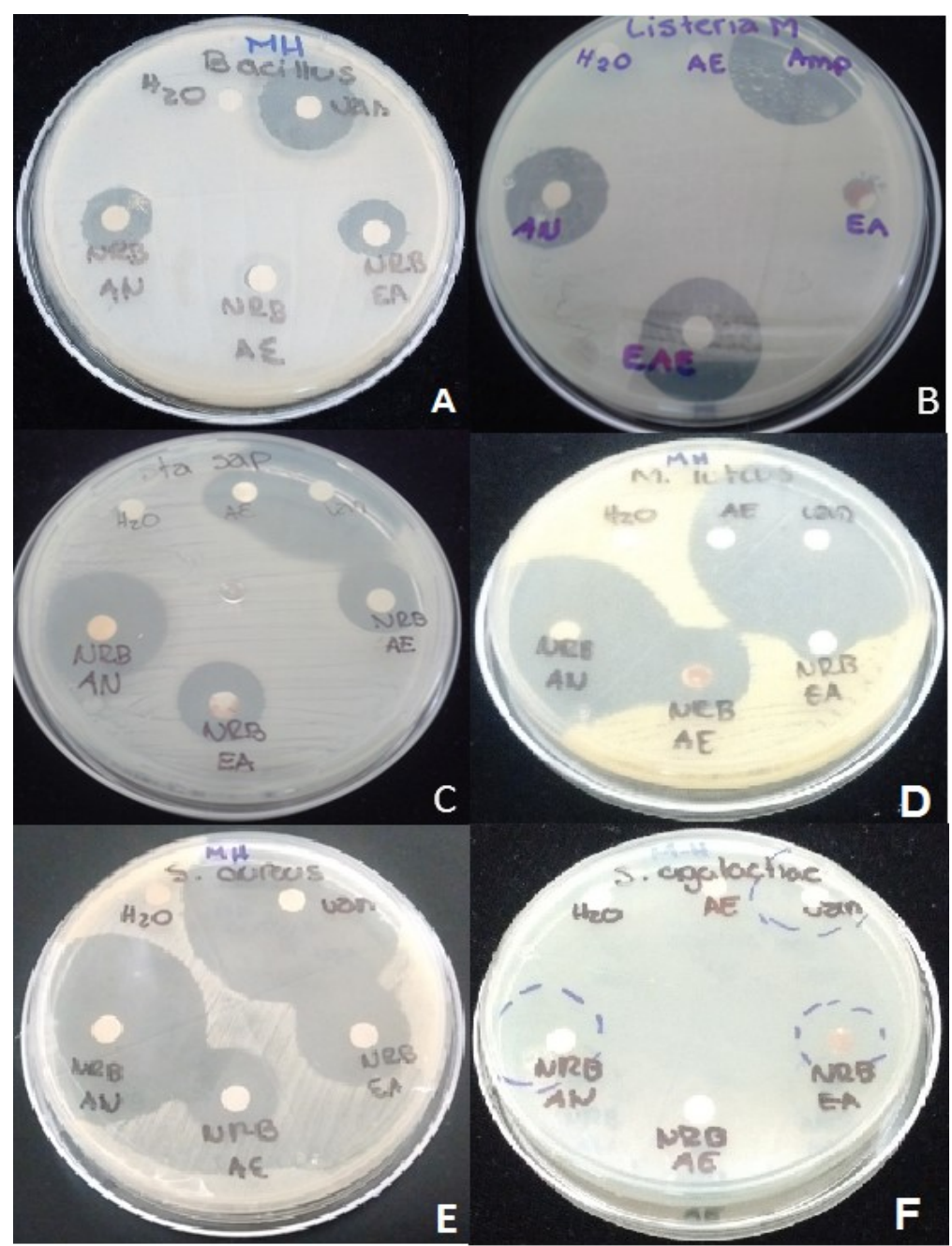

Figure 2. Determination of antibacterial activity of secondary metabolites of the crude extract of ELI149 (NRB) Bacillus sp. strain by agar-diffusion method to the following gram-positive bacteria; A) $B$. cereus, B) L. monocytogenes, C) S. saprophyticus, D) M. luteus, E) S. aureus, F) S. agalactiae

Although the extract of ethyl acetate (AE) showed a good growth inhibition, in the same way the metabolites retained by amberlite showed a greater antibiotic power against all bacteria than the others extracts, indicating that amberlite XAD-16 is a good adsorbent resin to retain antibiotics (Table 2).

The diameters of the zones of inhibition of growth, measured in $\mathrm{mm}$, around the disks against gram positive and gram-negative bacteria, respectively, both in LB and Muller-Hinton (MH) agar plates, showing an increase of the diameters of the zones of inhibition around the disks in the last case, due to the capacity of this agar to spread the antibiotics. In addition, all tested gram positive and gram-negative bacteria were sensible to the amberlite extract of ELI149 (NRB) strain. 
Table 2. Diameters (mm) of the zones of inhibition of growth of gram-positive and gram-negative bacteria.

\begin{tabular}{|c|c|c|c|c|c|c|}
\hline Strain & $\begin{array}{c}E L I 149 \\
N R B E A \\
M H\end{array}$ & $\begin{array}{c}E L I 149 \\
N R B A E \\
M H\end{array}$ & $\begin{array}{c}E L I 149 \\
N R B A N \\
M H\end{array}$ & $\begin{array}{c}A m p / \text { Van } \\
M H\end{array}$ & $\begin{array}{c}E L I 149 \\
N R B \\
L B\end{array}$ & $\begin{array}{c}A m p / V a n \\
L B\end{array}$ \\
\hline S. saprophyticus & 17 & 16 & 23 & 30 & 17 & 30 \\
\hline L. monocytogenes & 6 & 20 & 20 & 30 & 20 & 28 \\
\hline S. agalactiae & 17 & 0 & 21 & 25 & 12 & 21 \\
\hline S. aureus & 23 & 16 & 44 & 50 & 25 & 45 \\
\hline B. cereus & 13 & 0 & 13 & 20 & 10 & 19 \\
\hline M. luteus & 17 & 20 & 40 & 43 & 36 & 40 \\
\hline S.choleraesuis & 14 & 7 & 25 & 30 & 7 & 22 \\
\hline E.coli & 16 & 0 & 19 & 20 & 7 & 18 \\
\hline K.pneumoniae & 0 & 0 & 11 & 15 & 0 & 8 \\
\hline Shigella sp & 0 & 6 & 20 & 26 & 12 & 24 \\
\hline P. aeruginosa & 0 & 0 & 10 & 0 & 7 & 7 \\
\hline V.parahaemolyticus & 0 & 8 & 15 & 33 & 10 & 10 \\
\hline V.cholerae & 14 & 14 & 14 & 18 & 14 & 10 \\
\hline S. marcescens & 30 & 20 & 48 & 60 & 45 & 36 \\
\hline
\end{tabular}

\section{Molecular characterization}

With these promising results in hands it was necessary to identify unequivocally the strain. Respect to the phenotypic characterization of the strain ELI149 (NRB) the cells were examined for morphology and phase-contrast microscopy. The colony morphology which was large, cream colored, brilliant, mucoid, circular, flat and erose, the presence of parasporal body and the absence of crystal proteins indicated that it was Bacillus sp. A molecular characterization, showed a band of 1.5 $\mathrm{Kb}$, as shown in Figure 3A. A subsequent purification of the PCR product was done following the protocol of QUIAGEN QIAquick kit (Figure 3B).

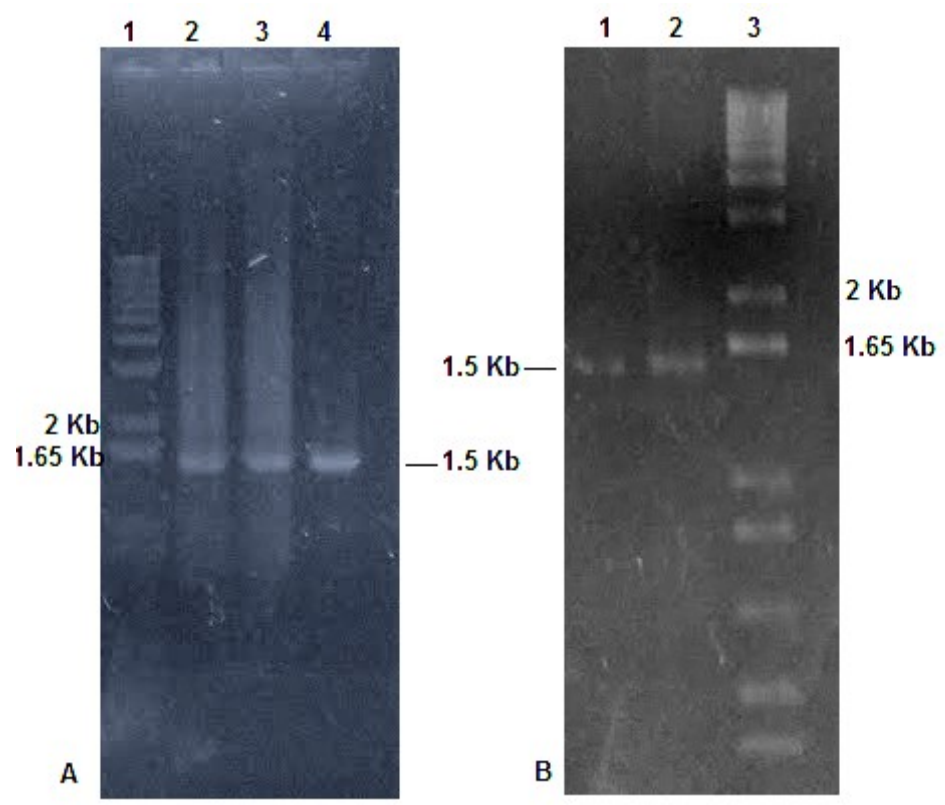

Figure 3. Amplification of the 16S rRNA gene in Bacillus ELI149 (NRB) strain by PCR. A) Detection of 16S rRNA gene in genomic DNA by PCR: Lane 1: DNA molecular weight marker $1 \mathrm{~Kb}$ plus ladder (Invitrogen), Lane 2, 3 and 4: amplification of the 16S rRNA gene from ELI149 (NRB) strain; B) PCR product purified for sequencing: Lane 1 and 2: amplification product of 16S rRNA gene from ELI149 (NRB) strain purified by QUIAGEN kit, Lane 3: DNA molecular weight marker $1 \mathrm{~Kb}$ plus ladder (Invitrogen). 


\section{Sequencing and analysis of 16S rRNA genes}

Sequence comparison of $B$. amyloliquefaciens sequence with those deposited with NCBI-GenBank showed 94\% similarity with five mismatches. This sequence similarity was further supported by the maximum-likelihood (ML) tree (Figure 4). The constructed phylogenetic tree using the 16S rRNA gene sequences of the related members from Bacillus (B. subtilis, B. endophyticus, $B$. cereus, B. anthracis, B. thuringiensis, and $B$. amyloliquefaciens) revealed that the strain ELI149 was grouped with $B$. amyloliquefaciens and is phylogenetically separated from another Bacillus species.

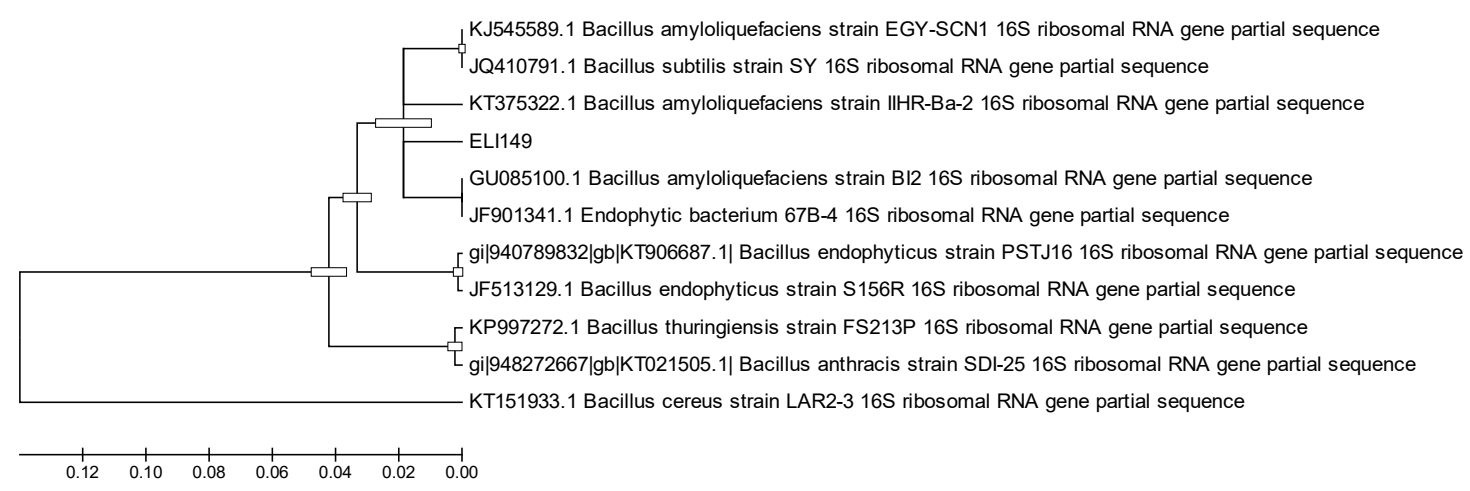

Figure 4. The maximum-likelihood (ML) phylogenetic tree based on 16SrDNA gene sequences of Bacillus spp. depicting the phylogenetic relationship between ELI149 strain and other representatives of the Bacillus genera. Tree constructed employing MEGA 5.0 (TAMURA et al., 2011). The tree was drawn to scale, with branch lengths measured in the number of substitutions per site. Bootstrap values from 500 replicates.

The isolate obtained in this study ELI149 showed more similarity to Bacillus amyloliquefaciens strain IIHR-Ba-2 $16 \mathrm{~S}$ ribosomal RNA gene, partial sequence (GenBank accession
KT375322.1). In table 3 are shown the sequences of Bacillus spp. used in this study and the nucleotide identity of them comparing with the sequence of the strain ELI149 (NRB).

Table 3. RNAr 16S sequences of Bacillus sp compared in this study for nucleotide identity percentage.

\begin{tabular}{|c|c|c|}
\hline Compared Sequences & $\begin{array}{l}\text { Nucleotide } \\
\text { identity }\end{array}$ & $\begin{array}{l}\text { NCBI-GenBank } \\
\text { accession number }\end{array}$ \\
\hline $\begin{array}{l}\text { Bacillus amyloliquefaciens strain IIHR-Ba-2 } 16 \mathrm{~S} \text { ribosomal RNA gene } \\
\text { partial sequence }\end{array}$ & $94 \%$ & KT375322.1 \\
\hline $\begin{array}{l}\text { Bacillus amyloliquefaciens strain EGY-SCN1 } 16 \mathrm{~S} \text { ribosomal RNA gene } \\
\text { partial sequence }\end{array}$ & $94 \%$ & KJ545589.1 \\
\hline Bacillus amyloliquefaciens strain BI2 16S ribosomal RNA gene partial & $94 \%$ & GU085100.1 \\
\hline Endophytic bacterium 67B-4 16S ribosomal RNA gene partial sequence & $94 \%$ & JF901341.1 \\
\hline Bacillus subtilis strain SY 16S ribosomal RNA gene partial sequence & $94 \%$ & JQ410791.1 \\
\hline $\begin{array}{l}\text { Bacillus endophyticus strain PSTJ16 16S ribosomal RNA gene partial } \\
\text { sequence }\end{array}$ & $89 \%$ & KT906687.1 \\
\hline $\begin{array}{l}\text { Bacillus endophyticus strain S156R } 16 \mathrm{~S} \text { ribosomal RNA gene partial } \\
\text { sequence }\end{array}$ & $88 \%$ & JF513129.1 \\
\hline $\begin{array}{l}\text { Bacillus thuringiensis strain FS213P } 16 \mathrm{~S} \text { ribosomal RNA gene partial } \\
\text { sequence }\end{array}$ & $87 \%$ & KP997272.1 \\
\hline Bacillus anthracis strain SDI-25 16S ribosomal RNA gene partial sequence & $87 \%$ & КT021505.1 \\
\hline $\begin{array}{l}\text { Bacillus cereus sequence strain LAR2-3 16S ribosomal RNA gene partial } \\
\text { sequence }\end{array}$ & $77 \%$ & KT151933.1 \\
\hline
\end{tabular}


Adsorbent resins have gained significant importance in the recovery of compounds and antibiotics, particularly, because of the advantages during production processes and recovery of bioproducts (CASEY et al., 2007). These resins have been used with success in the identification and characterization of antibiotics and other secondary metabolites specially amberlite XAD-16, which is a macroreticular, no ionic resin that adsorbs and releases substances through hydrophobic and polar interactions and has been used for the recovery of antibiotics (ROMERO-TABAREZ et al., 2006; SIERRA GARCÍA et al., 2012). In this work the extraction of the secondary metabolites was done with adsorbent resin XAD-16 and with ethyl acetate solvent, giving a better result the first, confirming the data reported in the literature. The results shown here indicated that among several strains that were probed, one strain called ELI149 (NRB) exhibited remarkable antagonistic activity against all probed bacteria both gram-positive and gram-negative, showing a wide spectrum of activity, as shown in Table 1 and 2. This strain had been probed against several fungi in a previous work of our group showing a remarkable antifungal activity and producing a cellular damage on several fungi
(SANSINENEA et al., 2017). The molecular characterization of this strain indicated that ELI149 (NRB) strain was $B$. amyloliquefaciens, a bacterium with high capacity to produce several secondary metabolites with capacity to inhibit plant fungal pathogens and several bacteria (CHEN et al., 2009).

\section{CONCLUSIONS}

The strain characterized as $B$. amyloliquefaciens exhibited a strong inhibitory activity against many bacteria that are important to human health.

A biotechnology challenge will be the purification of secondary metabolites that secretes the Bacillus amyloliquefaciens ELI149 strain to know which metabolites extracted from amberlite are the responsible of the bacteria growth inhibition. This can lead to the production of compounds with a benefit to improve the management of bacterial infections.

\section{ACKNOWLEDGEMENTS}

The authors acknowledge to VIEP (100518932 VIEP2018) for the financial support.

RESUMO: Um altamente potent metabolitos secundários-produzindo tensão de Bacillus esteve isolada de terra mexicana (Puebla Estatal), junto com outras cinquenta tensões. As cinquenta e uma tensões estiveram submetidas para extracção de metabolitos e avaliado como antibacterial contra várias bactérias. Os metabolitos ativos destas tensões estiveram extraídos utilizando amberlite XAD16 resina absorbente. O antibacterial actividade dos extractos crus de todas as tensões esteve actuado por método de difusão do disco na contramão alguns a grama patogénica positivo e grama-bactérias negativas. Entre todas tensões de Bacillus provaram, a maioria de potent tensão ELI149 (NRB) esteve seleccionado para caracterização molecular. A sequência de nucleótido do $16 \mathrm{~S}$ rRNA gene $(1.5 \mathrm{~Kb})$ desta tensão evidenced uma $94 \%$ semelhança com Bacillus amyloliquefaciens tensão IIHR-Ba-2, o qual mostrou a inibição mais alta na contramão as mais bactérias probed inclusive inibição maior que o antibiótico regular. Em conclusão, os metabolitos secundários extraíram de Bacillus amyloliquefaciens a tensão é altamente potent tão antibiótico na contramão as mais bactérias probed. Identificação do qual os metabolitos extraíram de amberlite é o responsável pela inibição de crescimento das bactérias será um repto.

PALAVRAS-CHAVE: Antibacteriano. Amberlite. Bacillus amyloliquefaciens. Metabólitos secundários.

\section{REFERENCES}

ARGUELLES-ARIAS, A.; ONGENA, M.; HALIMI, B.; LARA, Y.; BRANS, A.; JORIS, B.; FICKERS, P. Bacillus amyloliquefaciens GA1 as a source of potent antibiotics and other secondary metabolites for biocontrol of plant pathogens. Microbial Cell Factories, v. 8, p. 63, 2009. https://doi.org/10.1186/1475-2859-8-63

BRUNEL, A. S.; GUERY, B. Multidrug resistant (or antimicrobial-resistant) pathogens - alternatives to new antibiotics?. Swiss Medical Weekly, v. 147, p. w14553, 2017. https://doi.org/10.4414/smw.2017.14553. 
CASEY, J.T.; WALSH, P.K.; O'SHEA, D.G. Characterisation of adsorbent resins for the recovery of geldanamycin from fermentation broth. Separation and Purification Technology, v. 53, p. 281-288, 2007. https://doi.org/10.1016/j.seppur.2006.07.014.

CHEN, X.; SCHOLZ, R.; BORRISS, M.; JUNGE, H.; MOGEL, G.; KUNZ, S.; BORRISS, R. Difficidin and bacilysin produced by plant-associated Bacillus amyloliquefaciens Dare efficient in controlling fire blight disease. Journal of Biotechnology, v. 140, p. 38-44, 2009. https://doi.org/10.1016/j.jbiotec.2008.10.015

FELSENSTEIN, J. Evolutionary trees from DNA sequences: a maximum likelihood approach. Journal of Molecular Evolution, v. 17, p. 368-376, 1981. https://doi.org/10.1007/BF01734359.

NUTI, R.; GOUD, N.S.; SARASWATI, A.P.; ALVALA, R.; ALVALA, M. Antimicrobial Peptides: A Promising Therapeutic Strategy in Tackling Antimicrobial Resistance. Current Medicinal Chemistry v. 24, $p$ 4303-4314, 2017. https://doi.org/10.2174/0929867324666170815102441.

ROMERO-TABAREZ, M.; JANSEN, R.; SYLLA, M.; LÜNSFORD, H.; HÄUBLER, S.; SANTOSA, D.A.; TIMMIS, K.N.; MOLINARI, G. 7-O-malonyl macrolactin A, a new macrolactin antibiotic from Bacillus subtilis active against methicillin-resistant Staphylococcus aureus, Vancomycin-resistant enterococci, and a small-colony variant of Burkholderia cepacia. Antimicrobial Agents and Chemotherapy, v. 50, p. 17011709, 2006. https://doi.org/10.1128/AAC.50.5.1701-1709.2006.

SAMBROOK, J.; FRITSCH, F.; MANIATIS, T. Molecular Cloning: a Laboratory Manual, 2nd ed. Cold Spring Harbor Laboratory, Cold Spring Harbor, N.Y. 1989.

SANSINENEA, E. Bacillus thuringiensis biotechnology. Springer, Netherlands. 2012. https://doi.org/10.1007/978-94-007-3021-2

SANSINENEA, E.; ALMARAZ, M.; RAMÍREZ, M.D.; ORTIZ, A. Cellular damage of plant pathogenic fungi by antifungal compounds produced by Bacillus spp. Isolates. Chemistry and ecology, v. 32, p. 722-732, 2016. https://doi.org/10.1080/02757540.2016.1177518

SANSINENEA, E.; ORTIZ, A. Secondary metabolites of soil Bacillus spp. Biotechnology Letters, v. 33, p. 1523-1538, 2011. https://doi.org/10.1007/s10529-011-0617-5

SIERRA-GARCÍA, I.; ROMERO-TABAREZ, M.; ORDUZ-PERALTA, S. Determination of the antimicrobial and insecticidal activities in extracts produced by bacteria isolated from soil. Actualidades Biologicas, v. 96, p. $5-19,2012$.

TAMURA, K.; PETERSON, D.; PETERSON, N.; STECHER, G.; NEI, M.; KUMAR, S. MEGA5: Molecular Evolutionary Genetics Analysis using Maximum Likelihood, Evolutionary Distance, and Maximum Parsimony Methods. Molecular Biology and Evolution, v. 10, p. 2731-2739, 2011.

https://doi.org/10.1093/molbev/msr121.

VAISHNAV, P.; DEMAIN, A. L. Unexpected applications of secondary metabolites. Biotechnology Advances. v. 29, p. 223-229, 2011 https://doi.org/10.1016/j.biotechadv.2010.11.006

WRIGHT, G.D. Something old, something new: revisiting natural products in antibiotic drug discovery. Canadian Journal of Microbiology v. 60, p. 147-154, 2014. https://doi.org/10.1139/cjm-2014-0063. 